Vol 2. No 2. Agustus 2018

ISSN 2580-5029

\title{
Identifikasi Senyawa Aktif dari Ekstrak Daun Jambu Air (Syzygium aqueum) dengan Perbandingan Beberapa Pelarut pada Metode Maserasi
}

\author{
Eva Agustina ${ }^{1}$, Funsu Andiarna 1, , Nova Lusiana ${ }^{1}$, Risa Purnamasari1, Moch Irfan Hadi1 \\ 1 Universitas Islam Negeri Sunan Ampel Surabaya, Surabaya, Indonesia \\ *eva_agustina@uinsby.ac.id
}

\begin{abstract}
Water-cashew leaf (Syzygium aqueum) is known as one of the traditional medicine, to cure some infections due to antigen in the form of bacteria. This study aims to determine the content of active compounds contained in water leaf with some solvent in the process of maceration. Extraction method used in this research is cold extraction of maceration with solvent selection ie methanol $\left(\mathrm{CH}_{3} \mathrm{OH}\right)$, ethyl acetate and n-hexane. Phytochemical tests performed are saponin, flavonoid, alkaloid and triterpenoid / steroid test. From the test, it is known that the sample of cashew leaf extract with positive methanol solvent contains several active compounds such as flavonoids, saponins, alkaloids and triterpenoids. Water-leaf extract with acetyl and $n$-hexane-positive solvents contains several active compounds in the form of flavonoids, alkaloids and triterpenoids. The best solvent to obtain many active compounds is methanol.
\end{abstract}

Keywords: Guava water (Syzygium aqueum), maceration, active compound

\begin{abstract}
ABSTRAK
Daun jambu air (Syzygium aqueum) dikenal sebagai salah satu obat tradisional, untuk menyembuhkan beberapa infeksi akibat antigen berupa bakteri. Penelitian ini bertujuan untuk mengetahui kandungan senyawa aktif yang terdapat dalam daun jambu air dengan beberapa pelarut pada proses maserasi. Metode ekstraksi yang digunakan dalam penelitian ini adalah ekstraksi dingin berupa maserasi dengan pemilihan pelarut yakni metanol $\left(\mathrm{CH}_{3} \mathrm{OH}\right)$, etil asetat dan n-heksana. Uji fitokimia yang dilakukan adalah uji saponin, flavonoid, alkaloid dan triterpenoid/steroid. Dari uji yang dilakukan diketahui sampel ekstrak daun jambu air dengan pelarut metanol positif mengandung beberapa senyawa aktif berupa flavonoid, saponin, alkaloid dan triterpenoid. Ekstrak daun jambu air dengan pelarut etil asetat dan n-heksana positif mengandung beberapa senyawa aktif berupa flavonoid, alkaloid dan triterpenoid. Pelarut yang paling bagus untuk mendapatkan banyak senyawa aktif adalah metanol.
\end{abstract}

Kata kunci : Jambu air (Syzygium aqueum), maserasi, senyawa aktif

\section{PENDAHULUAN}

Infeksi merupakan penyebab

utama penyakit di dunia terutama di daerah tropis, seperti Indonesia

(Kuswandi et.al, 2001 dalam agustiningsih, 2010). Infeksi akibat 
bakteri ini dapat ditanggulangi dengan penggunaan antibakteri. Antibakteri merupakan senyawa-senyawa yang mampu menghambat pertumbuhan atau membunuh bakteri, terutama bakteri yang memberikan efek negatif bagi kesehatan manusia. Senyawa yang dapat membunuh bakteri diistilahkan dengan germisida, antiseptik, bakteriostatik, bakterisida, dan desinfektan (Putri, 2010).

Sifat-sifat bakteri berdasarkan toksisitasnya antara lain bakteriostatik merupakan senyawa antibakteri yang dapat menghambat pertumbuhan bakteri. Kemampuan antibakteri untuk menghambat pertumbuhan bakteri dapat dilihat dari kadar hambat minimum (KHM). Sedangkan bakterisida merupakan antibakteri yang mampu membunuh bakteri. Kemampuan antibakteri untuk membunuh pertumbuhan bakteri dapat dilihat dari kadar bunuh minimum (KBM). Kemampuan antibakteri dapat meningkat menjadi bakterisida apabila kemampuan untuk membunuh mikroba meningkat melebihi kadar minumumnya (Putri, 2010). Tanaman yang dapat dimanfaatkan sebagai agen anti bakteri alami adalah Syzygium aqueum atau jambu air. Jambu air merupakan http://jurnalsaintek.uinsby.ac.id/index.php/biotropic anggota dari family myrtaceae yang merupakan tanaman asli Malaysia dan Indonesia serta dikenal dengan nama lokal jambu air. Ekstrak etanol daun $S$. aqueum mengandung beberapa jenis senyawa metabolit diantaranya adalah adanya enam jenis flavonoid yaitu, 4hydmyricetinroxybenzadehyde, myricetin-3-0-rhamnoside, phloretin, myrigalone-B (Hariyanti, dkk. 2015).

Daun S. aqueum mengandung senyawa felonik. Menurut Wong dan Lai (1996) genus Syzygium mengandung terpenoid dan $\gamma$ terpinene dalam jumlah tinggi. Tanin juga ditemukan dalam daun spesies $S$. aqueum (Okuda dkk., 2009).

Daun jambu air mengandung acutissimin A, casuarinin, Eugenigradin A, eugeniin, 4,6 - hexahydroxy diphenoylglucose, grandinin, penduculagin, I - beta - 0 galloylpedunculagin, vescalagin, epi-(-)gallocatechin, epi-(-)-gallocatechin-3-0gallate, prodelphinidin B-2 3,3-di-Ogallate (Okuda dkk., Nonaka G.I dkk., dalam WHO, 2009). Pengambilan senyawa aktif dari daun jambu air dilakukan dengan cara ekstraksi.

Salah satu contoh teknik ekstraksi adalah maserasi yang merupakan metode ekstraksi dingin karena pengerjaannya tidak 
membutuhkan suhu tinggi. Maserasi adalah proses penyaringan simplisia dengan cara perendaman menggunakan pelarut dengan sesekali pengadukan pada temperatur kamar. Maserasi yang dilakukan pengadukan secara terusmenerus disebut maserasi kinetik sedangkan yang dilakukan pengulangan panambahan pelarut setelah dilakukan penyaringan terhadap maserat pertama dan seterusnya disebut remaserasi (Depkes RI, 2000 ). Senyawa metabolit sekunder yang diperoleh dari ekstraksi daun jambu biji tergantung dari pelarut yang digunakan untuk mengestraknya.

Ekstraksi merupakan langkah awal yang dilakukan untuk mendapatkan senyawa yang akan diambil. Pemilihan metode ekstraksi disesuaikan dengan adanya senyawa yang terkandung didalamnya. Dalam hal ini digunakan maserasi dengan pelarut yang sesuai, yakni yang memenuhi kriteria yang ditetapkan. Dalam proses ekstraksi efektifitas penarikan senyawa aktif bergantung dari pelarut yang digunakan. Beberapa hal yang perlu diperhatikan dalam pemilihan pelarut antara lain toksisitas, kemudahan untuk diuapkan, selektivitas, kepolaran, dan harga pelarut (Akbar, 2010). Dalam penelitian ini digunakan beberapa pelarut dalam proses ekstraksi yaitu http://jurnalsaintek.uinsby.ac.id/index.php/biotropic pelarut metanol bersifat polar, etil asetat bersifat semi polar dan n-heksan bersifat non polar.

\section{METODE}

\section{Bahan}

Bahan-bahan yang digunakan dalam penelitian ini adalah Daun Jambu Air (Syzygium aqueum), metanol, etil asetat, n-heksana, aquades, kloroform, kalium iodida, iodium, asetat, $\mathrm{FeCl}_{3}$, $\mathrm{H}_{2} \mathrm{SO}_{4}$ pekat, dan $\mathrm{HCl}$.

\section{Alat}

Alat yang digunakan dalam penelitian ini adalah blender, alat maserasi, corong, kertas saring, erlenmeyer, tabung reaksi, beaker glass, kaca arloji, botol vial, timbangan digital, rotary evaporator.

\section{Preparasi Sampel}

Preparasi sampel dilakukan dengan cara lembaran daun jambu air yang telah dipisahkan dari tulang daun utamanya dan dipotong kecil - kecil. Dilakukan pengeringan menggunakan oven dengan suhu $60^{\circ} \mathrm{C}$ selama 24 jam. Setelah sampel berupa rajangan daun jambu air ini kering, dilakukan dekstruksi atau penghancuran menjadi serbuk menggunakan blander. 


\section{Ekstraksi sampel}

Ekstraksi sampel menggunakan metode dingin, yakni maserasi. Metode maserasi jenis ini digunakan untuk ekstraksi senyawa - senyawa yang kurang tahan panas. Ekstraksi dilakukan dengan menimbang 15 gr sampel daun jambu air bubuk, kemudian dilakukan perendaman menggunakan pelarut metanol sebanyak $100 \mathrm{ml}$ dan dihomogenkan. Sampel yang telah tercampur homogen dengan pelarut, ditutup menggunakan plastik wrap dan ditunggu hingga $3 \times 24$ jam atau selama 3 hari dengan dilakukan pengamatan setiap harinya untuk mengetahui penguapan pelarut yang terjadi.

Setelah dihasilkan rendaman sampel, dilakukan penyaringan. Filtrat dari penyaringan dipindahkan ke erlenmeyer lain dan ditutup dengan plastic wrap. Sedangkan, residu kembali direndam untuk proses remaserasi. Evaporasi dilakukan pada filtrat hingga menjadi pasta, kemudian dimasukkan kedalam botol vial dan ditutup menggunakan alumunium foil untuk mempercepat evaporasi dan menghasilkan pasta yang lebih kental.

\section{Uji fitokimia}

\section{a. Uji Triterpenoid}

Ekstrak daun jambu air dilarutkan dalam $3 \mathrm{~mL}$ klorofom, kemudian disaring dan filtrat ditetesi degan $\mathrm{H}_{2} \mathrm{SO}_{4}$ secara berkala hingga terjadi perubahan warna. Uji dikatakan positif triterpenoid apabila terbentuk warna kuning keemasan dan positif steroid apabila terdapat warna merah.

\section{b. Uji alkaloid}

Sampel dilarutkan dalam $10 \mathrm{~mL}$ $\mathrm{HCl}$, kemudian dipanaskan sambil terus diaduk. Kemudian dilakukan pendinginan dan dimasukkanserbuk $\mathrm{NaCl}$ sebanyak 1 sendok spatula, kemudian dihomogenkan dan disaring. Uji dikatakan positif apabila terdapat endapan.

\section{c. Uji Flavonoid}

Sampel uji dilarutkan dalam pelarut yang dilakukan dalam ekstraksi (metanol) sebanyak $2 \mathrm{ml}$. Kemudian ditetesi $\mathrm{FeCl}_{3}$, dan dikatakan positif apabila terdapat perubahan menjadi merah, hijau atau biru.

\section{d. Uji saponin}

Sampel dilarutkan dalam aquades sebanyak $5 \mathrm{ml}$ kemudian dikocok. Uji dikatakan positif apabila terdapat busa yang tidak hilang dalam pengocokan. 


\section{HASIL DAN PEMBAHASAN}

Manfaat beberapa tanaman sebagai obat pada umumnya disebabkan oleh aktifitas senyawa yang terdapat pada tanaman tersebut. Senyawa ini dikenal dengan sebutan metabolit sekunder. Metabolit sekunder diproduksi tanaman sebagai salah satu cara untuk kelangsungan hidupnya atau sebagai alat pertahanan diri. Metabolit sekunder ada yang secara alami terkandung dalam tanaman, ada pula metabolit yang baru terbentuk pada saat tanaman mengalami kontaaminasi dari lingkungan (Salempa, P., 2014).

Senyawa metabolit sekunder dapat diambil dengan cara ekstraksi. Metode ekstraksi yang digunakan adalah maserasi. Maserasi merupakan proses pengambilan senyawa aktif dari tanaman dengan perendaman menggunakan pelarut yang sesuai dengan dilakukan pengadukan pada temperatur ruang. Keuntungan metode maserai adalah caranya yang mudah dan tidak memerlukan pemanasan sehingga bahan alam kemungkinan kecil mengalami kerusak atau terurai (Susanty, 2016).

Prinsip kerja ekstraksi dengan metode maserasi adalah proses tercapainya kesetimbangan konsentrasi antara senyawa aktif pada tanaman http://jurnalsaintek.uinsby.ac.id/index.php/biotropic dengan yang telah berpindah kepelarut. Pengadukan dilakukan secara terusmenerus agar proses ekstrasi berjalan optimal. Proses pengulangan penambahan pelarut setelah dilakukan penyaringan maserat pertama dan seterusnya disebut remaserasi (Putri, 2010).

Dalam melakukan ekstraksi menggunakan maserasi digunakan pelarut yang sesuai dengan senyawa yang ingin di identifikasi, Pemilihan pelarut yang sesuai merupakan salah satu faktor penting yang diperlukan dalam proses maserasi. Pelarut yang digunakan haruslah pelarut yang mampu menyaring sebagaian besar metabolit sekunder yang digunakan sebagai senyawa target dalam simplisia (Depkes RI, 2008), salah satunya adalah metanol.

Metanol biasa digunakan sebagai pelarut organik, merupakan jenis alkohol yang mempunyai struktur paling sederhana, tetapi paling toksik pada manusia (Nabila, 2011). Metanol memiliki sifat universal dalam berperan sebagai pelarut, yakni mampu melarutkan analit yang memiliki sifat polar dan nonpolar. Metanol dapat menarik analit berupa alkaloid, steroid, saponin dan flavonoid yang berasal dari tanaman. Etil asetat merupakan pelarut 
semi polar yang mudah menguap, tidak beracun. Etil asetat memiliki nilai polaritas 0,38 dan titik didih 77,1 . Pemilihan etil asetat pada ekstraks ini dikarenakan kemampuannya dalam melarutkan komponen dari golongan steroid, terpenoid, alkoloid, flavonoid, dan glikosida (Laksmijenie et al., 2005). Sedangkan N-heksana adalah pelarut yang bersifat non polar (Susanti dkk, 2012). N-Heksana merupakan salah satu pelarut yang dapat dengan mudah menguap, sehingga ekstrak dapat dengan mudah diperoleh (Wardhani dan Sulistyani, 2012). Pelarut n-heksan yang bersifat non polar memiliki tetapan dielektrik yang rendah.

Senyawa metabolit sekunder yang terdapat dalam ekstrak metanol, etil asetat dan n-heksan jambu air dianalisis secara kualitatif dengan tes uji warna menggunakan beberapa pereaksi untuk golongan senyawa alkaloid, saponin, flavonoid dan triterpenoid. Pelarut-pelarut dapat mengestrak senyawa aktif berdasarkan prinsip like dissolve like'. Hasil skrining fitokimia ekstrak metanol, etil asetat dan nheksana disajikan pada Tabel 1.

Analisis kualitatif dengan uji alkaloid dilakukan dengan metode Mayer. Ekstak daun jambu biji ditambahkan asam $\mathrm{HCl}$, dicampur dan didinginkan pada temperatur ruang. Setelah dingin ditambahkan $\mathrm{NaCl}$ lalu diaduk dan disaring. Penambahan ekstrak dengan $\mathrm{NaCl}$ bertujuan untuk menghilangkan protein. Terdapatnya protein dapat memberikan reaksi palsu pada beberapa senyawa yang mengandung logam berat (Santos et al., 1998).

Filtrat yang diperoleh ditambahkan $\mathrm{HCl}$ beberapa tetes, kemudian dipisahkan menjadi 4 bagian yaitu A, B, C dan D. Filtrat A merupakan larutan blangko, filtrat $\mathrm{B}$ ditambah pereaksi Mayer, filtrat $\mathrm{C}$ ditambah pereaksi Wagner, dan filtrat D digunakan untuk uji penegasan.

Tabel 1. Uji Fitokimia ekstrak daun jambu biji dengan beberapa pelarut

\begin{tabular}{lllll}
\hline Kandung Kimia & \multicolumn{1}{c}{ Pengujian } & & Ket. & \\
\hline Alkaloid & & Me & ET & n-Hek \\
\hline Saponin & Uji Alkaloid & + & + & + \\
\hline Flavonoid & Uji saponin & + & - & - \\
\hline Triterpenoid & Uji Flavonoid & + & + & + \\
\hline
\end{tabular}


Keterangan:

$(+)=$ Ada,$(-)=$ tidak ada

$\mathrm{Me}=$ Metanol, $\mathrm{ET}=$ Etil Asetat, $\mathrm{n}$-Hek $=$ n-Heksana

Apabila terbentuk endapan pada penambahan pereaksi Mayer dan Wagner maka identifikasi menunjukkan adanya alkaloid. Uji penegasan dilakukan dengan menambahkan amonia $25 \%$ pada filtrat D sehingga PH mencapai 8-9. Setelah pH tercapai ditambahkan kloroform dan diuapkan untuk menghilangkan kloroform setelah terjadi reaksi. Selanjutnya ditambahkan $\mathrm{HCl}$, diaduk dan disaring. Tujuan penambahan $\mathrm{HCl}$ karena alkaloid merupakan senyawa yang bersifat basa sehingga dapat diekstrak dengan pelarut yang mengandung asam (Harborne, 1996). Filtratnya dibagi menjadi 3 bagian. Filtrat A sebagai blangko, filtrat $\mathrm{B}$ diuji dengan pereaksi Mayer, sedangkan filtrat $\mathrm{C}$ diuji dengan pereaksi Dragendorff. Terbentuknya endapan menunjukkan adanya alkaloid (Marliyana dkk, 2005).

Uji mayer terhadap ekstrak jambu air dengan pelarut metanol, etil asetat dan n-heksana menghasilkan endapan, hal ini mengindikasikan bahwa ekstrak ekstrak tersebut positif terdapat alkaloid.

Diketahui sampel setelah melalui uji alkaloid, menjadi berwarna hijau dengan endapan tipis pada ujung tabung reaksi.
Dan menyimpulkan bahwa uji ini mampu menggambarkan bahwa ekstrak metanol daun jambu air positif mengandung alkaloid.

Hasil positif analisis alkaloid dengan uji Mayer dapat diketahui dengan terbentuknya endapan putih. Endapan putih yang terbentuk merupakan kompleks kalium-alkaloid. Pereaksi Mayer diperoleh dari reaksi larutan merkuri (II) klorida ditambah kalium iodida akan membentuk endapan merah merkurium(II) iodida. Apabila kalium iodida yang ditambahkan berlebih maka akan terbentuk kalium tetraiodomerkurat (II) (Hammado dan Illing, 2013).

Senyawa alkaloid mengandung atom nitrogen yang mempunyai pasangan elektron bebas, sehingga dapat digunakan untuk membentuk ikatan kovalen koordinasi dengan ion logam (McMurry, 2004). Pada uji alkaloid dengan pereaksi Mayer, atom nitrogen pada alkaloid akan bereaksi dengan ion logam $\mathrm{K}^{+}$dari kalium tetraiodomerkurat (II) membentuk kompleks kalium-alkaloid yang mengendap. Reaksi yang terjadi pada uji Mayer ditunjukkan pada Gambar 1. 


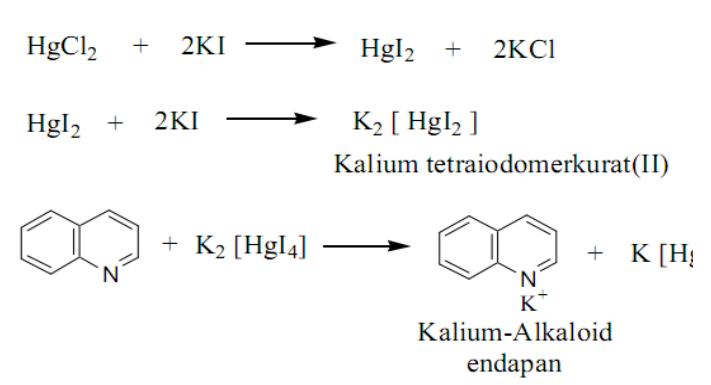

Gambar 1. Reaksi uji alkaloid (Nafisah, 2014)

Analisis metabolit sekunder selanjutnya adalah uji Saponin. Uji saponin dilakukan dengan metode Forth dengan cara menambahkan ekstrak daun jambu biji dengan akuades dan diamati perubahan yang terjadi. Apabila terbentuk busa yang tidak hilang selama 30 detik maka menunjukkan adanya saponin. Uji penegasan saponin dilakukan dengan cara sampel diuapkan sampai kering dan dicuci dengan n-heksana sampai filtrat jernih. Residu kemudian ditambahkan kloroform dan $\mathrm{Na}_{2} \mathrm{SO}_{4}$ anhidrat lalu disaring. Filtrat dibagi menjadi menjadi 2 bagian yaitu A dan B. Filtrat A sebagai blangko dan filtrat B ditambahi anhidrat asetat kemudian ditambah $\mathrm{H}_{2} \mathrm{SO}_{4}$ pekat dan diaduk kembali. Adanya cincin merah sampai coklat menunjukkan adanya saponin (Marliyana dkk, 2005).

Dari hasil uji diperoleh sampel positif mengandung saponin. Terbentuknya busa pada hasil uji menunjukkan adanya glikosida yang mempunyai kemampuan membentuk buih dalam air. Glikosida berfungsi sebagai gugus polar dan gugus steroid dan terpenoid sebagai gugus nonpolar. Senyawa yang memiliki gugus polar dan nonpolar bersifat aktif permukaan sehingga saat dikocok dengan air, saponin dapat membentuk misel. Pada struktur misel gugus polar menghadap keluar karena mengikat air (hidrofil) sedangkan gugus nonpolar menghadap kedalam karena takut dengan air (hidrofob) (Agustina dkk, 2016). Keadaan ini yang tampak seperti busa, dari sifat itulah uji adanya saponin dalam sampel dilakukan dengan melihat kemampuan sampel dalam membentuk busa/buih.

Dalam uji yang dilakukan untuk menentukan keberadaan saponin ini ditandai dengan adanya buih dan menyatakan bahwa ekstrak daun jambu air mengandung senyawa aktif berupa saponin.

Uji selanjutnya adalah uji flavonoid. Ekstrak jambu biji dicuci dengan nheksana sampai jernih. Residu dilarutkan dalam etanol kemudian disaring. Filtrat dibagi menjadi 4 bagian yaitu A, B, dan C. Filtrat A sebagai blangko, filtrat B ditambahkan $\mathrm{HCl}$ pekat kemudian dipanaskan pada penangas air, jika terjadi perubahan warna merah tua sampai ungu 
menunjukkan hasil yang positif. Filtrat $\mathrm{C}$ ditambahkan $\mathrm{HCl}$ dan $\mathrm{FeCl}_{3}$ kemudian diamati perubahan warna yang terjadi. Warna merah sampai jingga karena adanya senyawa flavon, warna merah tua karena adanya senyawa flavonol atau flavonon, warna hijau sampai biru akibat senyawa aglikon atau glikosida (Marliyana dkk, 2005).

Senyawa saponin dapat digunakan sebagai agen antimikroba (Robinson, 1995). Senyawa saponin dapat merusak membran sitoplasma dan membunuh sel (Assani, 1994). Sedangkan senyawa flavonoid dapat mendenaturasi protein sel bakteri dan merusak membran sel tanpa dapat diperbaiki lagi (Pelczar dan Chan, 1988 dalam Putri, 2010).

Telah dilakukan analisis terhadap sampel daun jambu air yang diekstraksi dengan pelarut metanol dan diperoleh bahwa sampel yang diuji mengandung senyawa flavonoid. Senyawa flavonoid merupakan senyawa yang bersifat polar karena memiliki gugus hidroksil $(-\mathrm{OH})$ yang tidak tersubstitusi sehingga dapat terbentuk ikatan hidrogen. Dalam proses ekstraksi, senyawa aktif dalam suatu tanaman akan mudah terlarut atau terikat oleh pelarut sesuai dengan sifat kepolarannya. Sehingga larutan metanol yang bersifat polar akan lebih mudah mengesktrak senyawa flavonoid dalam jaringan tanaman. Hal ini sesuai dengan prinsip "like disolve like" dimana larutan yang bersifat polar akan berikatan dengan senyawa polar lainnya begitu pula sebaliknya, larutan yang bersifat nonpolar akan mengikat senyawa nonpolar (Agustina dkk, 2016). Dalam uji yang dilakukan ini didapatkan warna biru gelap yang menandai adanya flavonoid didalamnya.

Telah dilakukan analisis terhadap sampel daun jambu air yang diekstraksi dengan pelarut metanol dan diperoleh bahwa sampel yang diuji dengan uji sarkowski mengandung senyawa Triterpenoid dengan terjadi perubahan warna menjadi warna kuning keemasan/ jingga. Triterpenoid adalah senyawa yang kerangka karbonya berasal dari enam satuan isoprene dan secara biosintesis diturunkan dari hidrokarbon C- 30 asiklik, yaitu skualena, senyawa ini tidak berwarna, berbentuk Kristal, bertitik leleh tinggi dan bersifat optis aktif. Senyawa triterpenoid dapat dibagi menjadi empat golongan, yaitu: triterpen sebenarnya, saponin, steroid, dan glikosida jantung (Harborne,1996).

Menurut Harborne (1987) bahwa kandungan terpenoid/steroid dalam tumbuhan diuji dengan menggunakan metode sarkowski yang nantinya akan memberikan warna jingga atau ungu 
untuk terpenoid dan warna ungu untuk steroid. Uji ini didasarkan pada kemampuan senyawa tritepenoid dan steroid membentuk warna oleh $\mathrm{H}_{2} \mathrm{SO}_{4}$ pekat pada pelarut asetat glacial yang membentuk warna jingga.

Dalam penilaian kali ini didapatkan warna kuning emas dengan cincin hijau, yang menggambarkan bahwa ekstrak metanol daun jambu air mengandung senyawa aktif berupa triterpenoid.

\section{KESIMPULAN}

Daun jambu air (Syzygiun aqueum) diekstraksi dengan metode maserasi dengan berbagai pelarut. ekstrak daun jambu air dengan pelarut metanol positif mengandung beberapa senyawa aktif berupa flavonoid, saponin, alkaloid dan triterpenoid. Ekstrak daun jambu air dengan pelarut etil asetat dan n-heksana positif mengandung beberapa senyawa aktif berupa flavonoid, alkaloid dan triterpenoid. Pelarut yang paling bagus untuk mendapatkan banyak senyawa aktif adalah metanol.

\section{DAFTAR PUSTAKA}

Agustina. S., Ruslan, dan Agrippina Wirangningtyas. 2016. Skrining Fitokimia Tanaman Obat Di Kabupaten Bima. Indonesian E-
Journal Of Appliied Chemistry.Vol 4 (1).

Depkes RI. 2000. Parameter Standar Umum Ekstrak Tumbuhan Obat. Departemen Kesehatan Republik Indonesia, Jakarta.

Hammado N dan Illing I. 2013. Identifikasi Senyawa Bahan Aktif Alkaloid Pada Tanaman Lahuna (Eupatorium odoratum). Jurnal Dinamika. Vol 04, No 2

Harborne, J., 1996. Metode Fitokimia: Penuntun Cara Modern Menganalisis Tumbuhan. Cetakan kedua. Penerjemah: Padmawinata, K. dan I. Soediro. ITB, Bandung.

Hariyati, T., Soelistya D.D.J., Andayani, Y., 2015. Pengaruh Ekstrak Etanol Daun Jambu Air (Syzygium aqueum) Terhadap Bakteri Isolat Klinis. Jurnal Penelitian Pendidikan IPA. Vol 1, No 2

Marliyana, S.D., Venty.S., dan Suyono. 2005. Skrining Fitokimia Dan Analisis Kromatografi Lapis Tipis Komponen Kimia Buah Labu Siam (Sechium edule Jacq. Swartz.) Dalam Ekstrak Etanol. Biofarmasi 3. Vol (1) 26-31.

McMurry, J. and R.C. Fay. 2004. McMurry Fay Chemistry. 4th edition. Pearson Education International, Belmont, CA.

Minhatun Nafisah, Tukiran, Suyatno, dan Nurul Hidayati. 2014. Uji Skrining Fitokimia Ada Ekstrak Heksan, Kloroform Dan Metanol Dari Tanaman Patikan Kebo (Euphorbiae hirtae). Jurusan Kimia FMIPA Universitas Negeri Surabaya, Prosiding Seminar Nasional Kimia 
Nabila, N. 2011. Pengaruh Pemberian Methanol Dan Etanol Terhadap Tingkat Kerusakan Sel Hepar Tikus Wistar. Jurnal Medika Muda. Vol (10) 1-8.

Okuda, T.; Yoshida, T.; Hatano, T.; Yazaki, K.; Ashida, M. 2009. Ellagitannins of the casuarinaceae, stachyuraceae and myrtaceae. Phytochemistry. 21, 2871.

Putri, Z,F. 2010. Uji Aktivitas Antibakteri Ekstrak Etanol Daun Sirih (Piper betle L.) Terhadap Propionibacterium acne dan Staphylococcus aureus multiresisten. Skripsi. Fakultas Faramasi. Universitas Muhammadiyah Surakarka, Surakarta.

Salempa, P., 2014. Isolasi dan Identifikasi Senyawa Metabolit Sekunder ekstrak n-Heksan daun Tumbuhan Maja (Aegle marmelos Linn.). Jurnal Sainsmat, Halaman 185-190 Vol. III, No. 2

Santos, A.F., B.Q. Guevera, A.M. Mascardo, and C.Q. Estrada. 1978. Phytochemical, Microbiological and Pharmacological, Screening of Medical Plants. Research Center University of Santo Thomas, Manila.

Susanti,at,al. 2012. Polaritas Pelarut sebagai Pertimabangan dalam Pemilihan Pelarut untuk Ekstraksi Minyak Bekatul dari Bekatul Varietas Ketan COriza Sativa Glatinosa). Simposium Nasional RAPI XI FT UMS,Yogyakarta

Susanty, dan Bachmid F. 2016. Perbandingan Metode Ekstraksi Maserasi Dan Refluks Terhadap Kadar Fenolik Dari Ekstrak Tongkol Jagung (Zea mays L.). KONVERSI Vol. 5 No. 2
Wardhani, L. K. Dan N. Sulistyani. 2012. Uji Aktivitas Antibakteri Ekstrak Etil Asetat Daun Binahong (Anredera Scandens (L.) Moq.) Terhadap Shigella Flexneri Beserta Profil Kromatografi Lapis Tipis. Jurnal Ilmiah Kefarmasian. Vol. 2(1): 1-16. 